\title{
Cost-effectiveness of palivizumab compared to no prophylaxis in term infants residing in the Canadian Arctic
}

\author{
Anna Banerji MPH MD, Kaspar Ng BPharm MD, Theo J. Moraes MD PhD, Vladimir Panzov MD, \\ Joan Robinson MD, Bonita E. Lee MD
}

See also www.cmajopen.ca/lookup/doi/10.9778/cmajo.20150051

\section{Abstract}

Background: Hospital admissions for respiratory syncytial virus infection result in large health expenditures for Inuit infants. Palivizumab has been shown to be highly effective in reducing such admissions in preterm Inuit infants. We performed a cost-effectiveness analysis estimating the incremental cost-effectiveness ratio (ICER) for palivizumab prophylaxis per admission related to respiratory syncytial virus avoided in healthy term infants across the Canadian Arctic.

Methods: We compared universal palivizumab prophylaxis in term infants less than 6 months of age to no prophylaxis in 8 Arctic regions: the Northwest Territories, Nunavut, Nunavut without Iqaluit, the 3 subregions of Nunavut (Kitikmeot, Kivalliq and Qikiqtaaluk), the Qikiqtaaluk Region without Iqaluit, and Nunavik (northern Quebec). Costs were acquired from the territorial governments, hospitals and contracted agencies. The perspective is that of the public payer, with a 6-month timeline. In scenario A, universal prophylaxis was provided until the end of the respiratory syncytial virus season, and in scenario B, infants received prophylaxis until 5 months of age. The ICERs of scenario A were compared with those of scenario $B$.

Results: Under scenario A, the cost per admission avoided was as high as $\$ 546115$ in the Northwest Territories, compared with a cost savings of \$36 145 in the Kitikmeot Region. Under scenario B, the ICER showed cost savings of \$48 549 in the Kitikmeot Region and \$2731 in the Kivalliq Region, with low ICERs in Nunavik of \$15 601.

Interpretation: Considerable cost savings were found for the Kitikmeot Region with universal palivizumab prophylaxis in term infants with both scenarios, whereas cost savings were found for the Kivalliq Region with scenario B. Stopping prophylaxis at 5 months of age was a more cost-effective strategy in all regions except the Kitikmeot Region. Nunavik had low ICERs, and prophylaxis should be considered for this region.

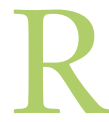

espiratory syncytial virus is the most important viral respiratory pathogen in young children. ${ }^{1}$ In 2005 , this virus was responsible for about 3.4 million hospital admissions and 200000 deaths globally in children less than 5 years of age. ${ }^{1}$ Infants in Arctic Canada have extremely high rates of lower respiratory tract infections, ${ }^{2-6}$ and respiratory syncytial virus has been identified as the major pathogen in these infections. ${ }^{5,7}$ In the rural communities of the Qikiqtaaluk Region of Nunavut, the rate of admission for infection due to the virus in 2002 was 166 per 1000 infants in their first year of life, ${ }^{7}$ compared to a North American estimate of $10-30$ per 1000 infants. $^{8}$

Most Inuit infants in the Canadian Arctic have access to local health centres only. Infants requiring hospital admission are evacuated by air over large distances to regional or tertiary hospitals in more southern parts of Canada. High rates of respi- ratory syncytial virus infection combined with expensive medical evacuations make hospital admissions for these infections the greatest health expenditure for infants in Nunavut. ${ }^{7,9}, 10$

Palivizumab, a monoclonal antibody against respiratory syncytial virus, was licensed in Canada in 2002. By 2005, government-funded palivizumab programs had been implemented across the Canadian Arctic. Currently, the drug is

Competing interests: Joan Robinson received grants from Abbott and Medimmune during the conduct of the study.

This article has been peer reviewed.

Correspondence to: Anna Banerji, anna.banerji@utoronto.ca

CMAJ Open 2016. DOI:10.9778/cmajo.20150052 
given by monthly injections during the respiratory syncytial virus season to infants considered at high risk for severe disease (i.e., those born before 36 weeks' gestation and those with substantial congenital heart or chronic lung disease). ${ }^{11,12}$ Recently, palivizumab was estimated to have an effectiveness of $96 \%$ in Inuit infants less than 6 months of age at high risk at the beginning of the respiratory syncytial virus season. ${ }^{13}$ In 2002, a budget impact analysis in the Qikiqtaaluk Region showed a potential cost savings associated with universal palivizumab prophylaxis in Inuit infants of all gestational ages in the rural communities. ${ }^{7}$ Subsequently, the Canadian Paediatric Society recommended considering palivizumab administration at the start of the respiratory syncytial virus season for term Inuit infants less than 6 months of age who resided in remote communities with a persistent high rate of hospital admission for infection due to this virus. ${ }^{11,12}$ A systematic review of international palivizumab strategies for respiratory syncytial virus showed variability in results, with favourable cost profiles in some populations but not in others. ${ }^{14}$

The purpose of this project was to estimate the costeffectiveness of universal palivizumab prophylaxis at the beginning of the respiratory syncytial virus season in healthy term infants less than 6 months of age across the Canadian Arctic.

\section{Methods}

This study is a cost-effectiveness analysis in which we estimated the incremental cost-effectiveness ratio (ICER) per hospital admission prevented with palivizumab prophylaxis for 2 scenarios. We extracted data from a 2009 prospective surveillance study of hospital admission for lower respiratory tract infection among infants less than 6 months of age residing in the Canadian Arctic. ${ }^{10,15} \mathrm{We}$ selected 8 Arctic regions for the study: the Northwest Territories, Nunavut, Nunavut without Iqaluit, the 3 subregions of Nunavut (Kitikmeot, Kivalliq and Qikiqtaaluk), the Qikiqtaaluk Region without Iqaluit, and Nunavik (northern Quebec). Data were collected prospectively except for the Qikiqtaaluk Region, where data were collected retrospectively.

The respiratory syncytial virus season in the Canadian Arctic is typically delayed and long and often peaks in late spring. ${ }^{13}$ In $2009,96 \%$ of admissions for infection due to this virus occurred between Jan. 1 and June 30, the defined respiratory syncytial virus season in the Canadian Arctic. ${ }^{13}$ The lower respiratory tract infection and respiratory syncytial virus season in 2009 was the mildest in the previous 30 years. ${ }^{2-7}$

\section{Study population}

The study population consisted of healthy infants who resided in the Northwest Territories, Nunavut or Nunavik and who were born between July 1, 2008, and May 31, 2009. Exclusion criteria included gestational age less than 36 weeks and substantial underlying congenital heart disease or chronic lung disease. We obtained the total number of births in each region from Statistics Canada or the territorial governments. ${ }^{16}$ In Nunavut, for consecutive seasons since 2011 , about $8 \%$ of infants less than 6 months of age at the beginning of the respiratory syncytial virus season were already candidates for palivizumab administration (Dr. Maureen Baikie, Government of Nunavut: personal communication, 2012); thus, we estimated that $92 \%$ of this population were healthy term infants.

\section{Scenarios}

Palivizumab doses were scheduled monthly starting from the last week of December 2008 to the last week of May 2009 and were assumed to provide 1 month of protection. This analysis assumes $100 \%$ compliance and vial sharing. In scenario A, universal palivizumab prophylaxis for all healthy term infants who were less than 6 months of age as of Jan. 1, 2009 was compared to no prophylaxis (Figure 1). In scenario B, palivizumab prophylaxis for infants up to 5 months of age only (for 6 months of protection) was compared to no prophylaxis (Figure 2). This analysis assumed that births were equally distributed across the year. The maximum number of doses was 6 in both scenarios..$^{10}$ The 2 scenarios were analyzed in each of the 8 Arctic regions. In addition, the cost-effectiveness of scenario A was directly compared with that of scenario B. The study variables are detailed in Table 1 .

\section{Costs}

Costs were obtained directly from the hospitals, territorial governments and contracted agencies and are detailed elsewhere. ${ }^{10} \mathrm{We}$ calculated the costs related to admission due to respiratory syncytial virus for each infant in each region (Table 2). The main drivers for costs were related to transportation and admission, which were either actual or minimal estimates of costs (Table 1). Transportation costs included medical air evacuation from the residential community to regional and/or tertiary hospitals and return flight, estimated as an economy scheduled flight for 1 adult. This is likely an underestimate, as often infants are returned to their place of residence by air ambulance.

We calculated hospital costs based on per-diem rates differentiated by ward and intensive care unit. The emergency department assessment fee (which included hospital, physician and procedural fees) was estimated at $\$ 700$ for tertiary and $\$ 1000$ for regional hospitals. We estimated physician fees from the Ontario Health Insurance Plan Schedule of Benefits and Fees (mid-range) and did not include after-hour or call-in fees. ${ }^{17} \mathrm{We}$ estimated the cost of parental accommodation at a hotel at $\$ 150$ per day for tertiary admissions. The costs of expensive interventions such as high-frequency oscillation ventilation and resuscitation were not included in this analysis, ${ }^{15}$ nor were costs related to outpatient visits, readmissions or medication.

We calculated the cost of palivizumab at $\$ 225.75$ per $\mathrm{kg}$ of estimated weight based on Centers for Disease Control and Prevention growth charts, with $5 \%$ added for wastage ${ }^{18}$ and a $\$ 50$ administration fee per dose (Table 3). As palivizumab is routinely transported with other vaccines on regularly scheduled flights, we did not add any additional cost for transportation. All costs were calculated in 2011 Canadian dollars and 
were not discounted. The timeline was the 6-month respiratory syncytial virus season.

This economic evaluation was conducted from the public payer's perspective and included direct costs associated with prophylaxis of respiratory syncytial virus infection and medical care. Because the time span was limited to the 6-month respiratory syncytial virus season, discounting of costs and effects was not required.

\section{Outcomes}

The outcome was admission to hospital with infection due to respiratory syncytial virus between Jan. 1 and June 30, 2009. We used the rates of admissions for respiratory syncytial virus infection in 2009, as these were the lowest documented in the previous 30 years, ${ }^{2-7}$ to increase the generalizability to other years, which are likely to have equivalent or greater cost-effectiveness.

\section{Measurement of effectiveness}

The effectiveness of palivizumab in term infants is not known but is estimated to be similar to that in preterm Inuit infants in Nunavut during the 2009 respiratory syncytial virus season: $96 \%$, but as low as $88 \%$ on sensitivity analysis. ${ }^{10}$ As the effectiveness of palivizumab could be a major driver in the model, we conducted sensitivity analyses recalculating ICERs using $88 \%$ risk reduction in scenario $\mathrm{C}$.

\section{Analytical methods}

We calculated ICERs using an 88\%-96\% risk reduction, based on a study of preterm Inuit infants in Nunavut. ${ }^{13}$ Complete cost information was available for each admission. Palivizumab doses were scheduled monthly starting from the last week of December 2008 to the last week of May 2009 and were assumed to provide 1 month of protection. For sensitivity analysis, we also increased wastage from $5 \%$ to $15 \%$ in sce-

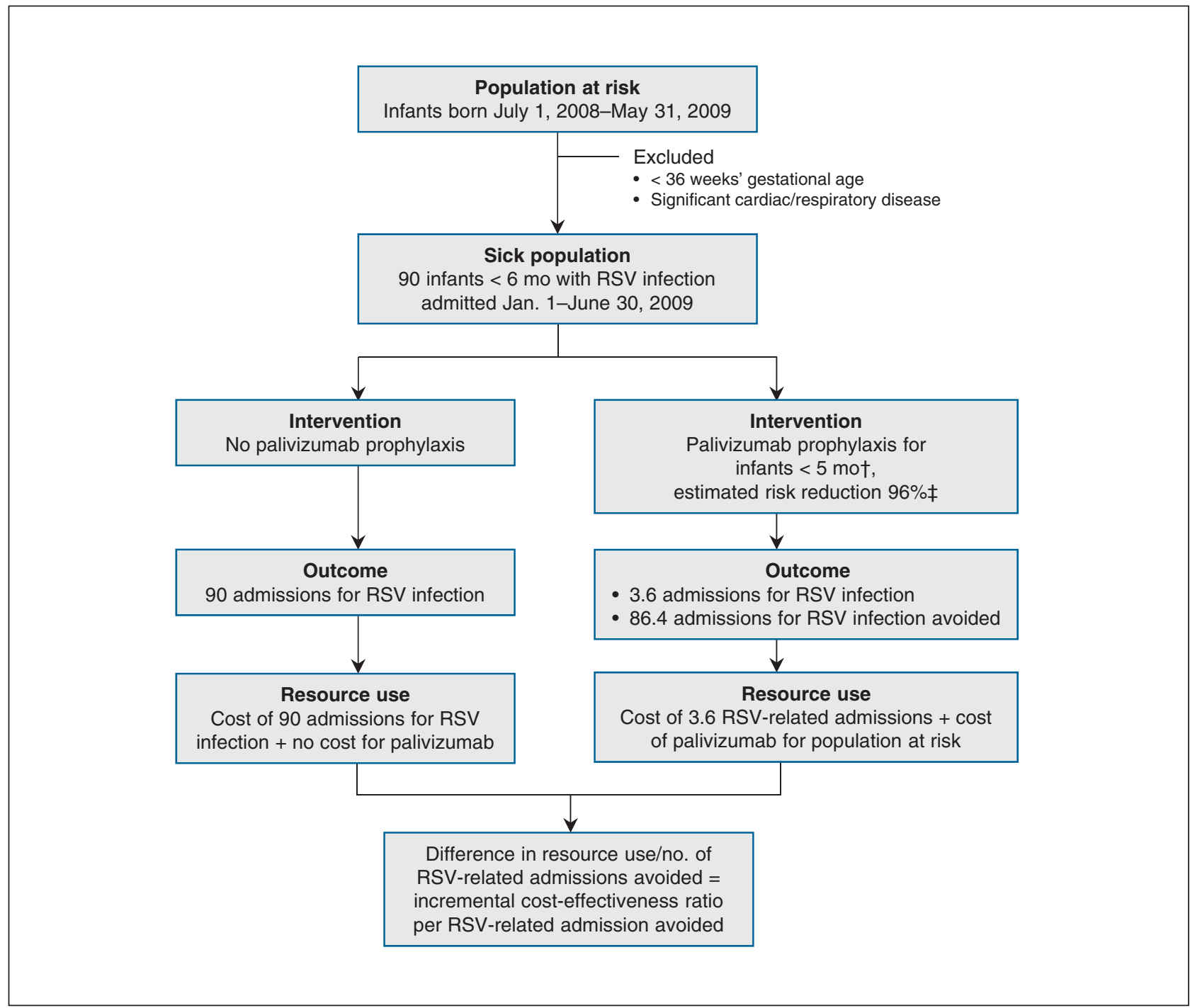

Figure 1: Incremental cost-effectiveness ratio for scenario A, palivizumab prophylaxis for healthy term infants across the Canadian Arctic compared with no prophylaxis for infants less than 6 months of age at or during the 2009 respiratory syncytial virus (RSV) season (Jan. 1-June 30). †Prophylaxis up to 5 months of age provides 6 months of protection. ¥Scenario C, sensitivity analysis using $78 \%$ risk reduction. 
nario C. This analysis assumes $100 \%$ compliance and vial sharing.

\section{Results}

There were 204 hospital admissions for lower respiratory tract infections among infants born after July 1, 2008 and admitted between Jan. 1 and June 30, 2009. Of the 204 infants, 184 (90.2\%) had testing for respiratory syncytial virus, with 101 positive results. Eleven of the 101 were excluded (9 preterm, 2 preterm with congenital heart disease), leaving 90 infants, of whom 74 were less than 6 months of age and 16 were 6 months of age or more at admission. The ICERs, rates of admission for respiratory syncytial virus infection and number needed to treat are given in Tables 4-6 for all scenarios.

There was a large range in ICERs per hospital admission avoided in scenario A, where it was as high as \$546 115 in the Northwest Territories, compared with a cost savings of up to \$36 145 in the Kitikmeot Region. Scenario B demonstrated a cost savings of \$48 549 in the Kitikmeot Region and \$2731 in

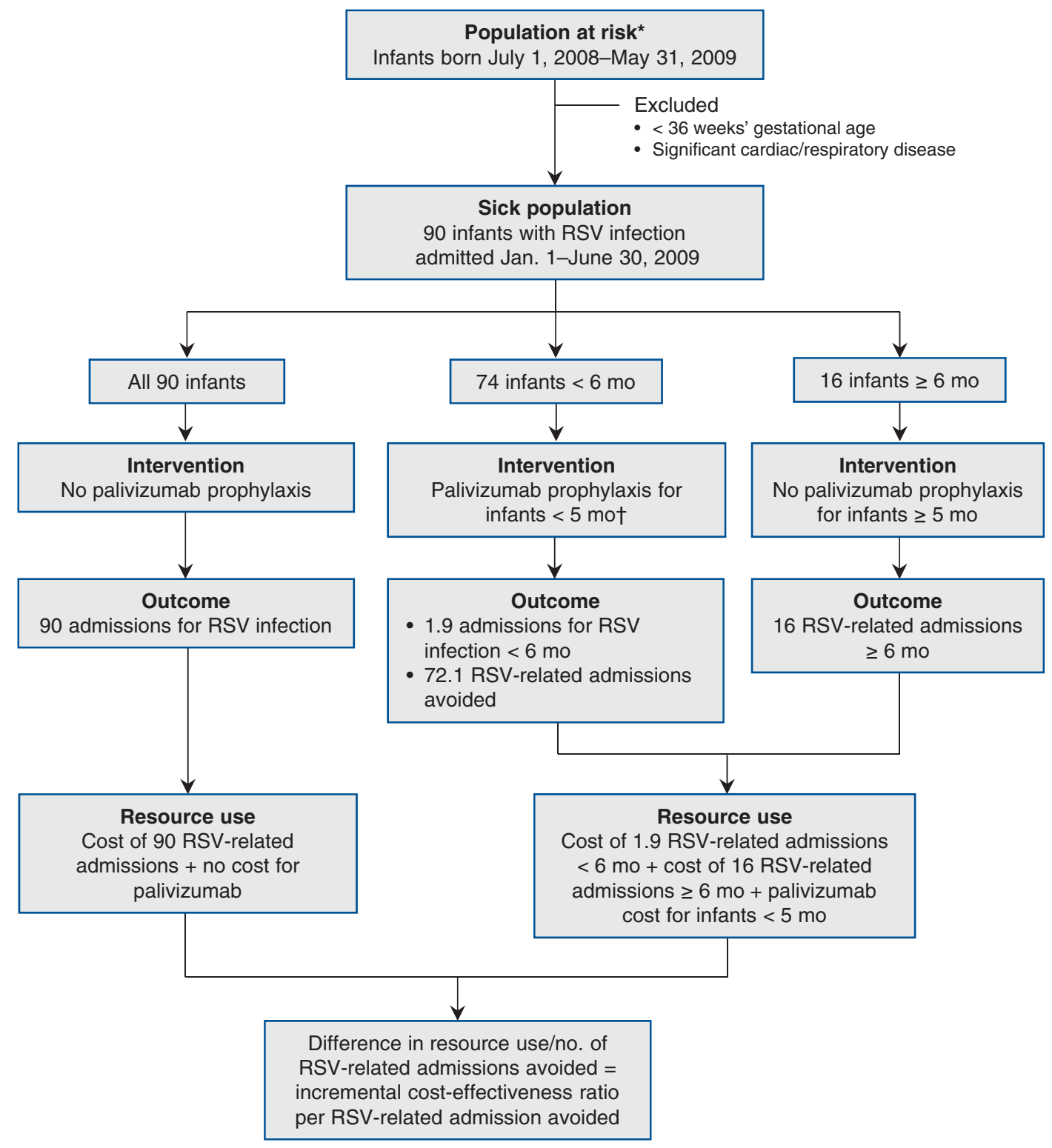

Figure 2: Incremental cost-effectiveness ratio for scenario B, palivizumab prophylaxis compared with no prophylaxis for healthy term infants across the Canadian Arctic up to 5 months of age. *Population at risk is fluid, with equal number meeting inclusion criteria (through birth) as exclusion criteria. †Estimated risk reduction $96 \%$. ‡Prophylaxis up to 5 months of age provides 6 months of protection. $\mathrm{RSV}=$ respiratory syncytial virus. 
Table 1: Variables for cost-effectiveness analysis of palivizumab prophylaxis in term Inuit infants admitted to hospital with infection due to RSV between Jan. 1 and June 30, 2009

\begin{tabular}{|c|c|c|c|}
\hline Variable & Estimate & $\begin{array}{l}\text { Range or alternative } \\
\text { estimate }\end{array}$ & Comments \\
\hline $\begin{array}{l}\text { Rate of RSV-related } \\
\text { admission }\end{array}$ & $\begin{array}{l}\text { Actual data for 2009: number of } \\
\text { admissions of healthy term } \\
\text { infants*/population at risk in } \\
\text { each region, January to June } \\
2009\end{array}$ & Minimum estimate & $\begin{array}{l}2009 \text { had the lowest rates of RSV-related } \\
\text { admissions documented in the previous } 30 \\
\text { years. }{ }^{2-7} \text { As other years are likely to have equal or } \\
\text { greater rates of RSV infection, cost-effectiveness } \\
\text { would be similar or greater. May be underestimate } \\
\text { as only } 90 \% \text { were tested for RSV. }\end{array}$ \\
\hline Births in 2009 & Actual number of births & - & Source: Statistics Canada or territorial governments \\
\hline Healthy term infants & 0.92 of births in 2009 & - & $\begin{array}{l}\text { Source: Dr. Maureen Baikie, Chief Medical Officer } \\
\text { of Health, Government of Nunavut. In } 2011-2013 \text {, } \\
9.3 \% \text { of the population received palivizumab each } \\
\text { year (estimate } 8 \% \text { of those aged }<6 \text { mo, } 1.3 \% \text { of } \\
\text { those aged } 6 \text { mo-2 yr). }\end{array}$ \\
\hline Population at risk & $51 / 72$ of healthy infants & - & Infants born July 1, 2008, to May 31, 2009 \\
\hline $\begin{array}{l}\text { Population that received } \\
\text { prophylaxis scenario } \mathrm{A}\end{array}$ & $51 / 72$ of healthy infants & - & $\begin{array}{l}\text { Prophylactic administration of palivizumab to all } \\
\text { infants born July 1, 2008, to May 31, } 2009 \text { (see } \\
\text { Table 3) }\end{array}$ \\
\hline $\begin{array}{l}\text { Population that received } \\
\text { prophylaxis scenario B }\end{array}$ & $6 / 12$ of healthy infants & - & $\begin{array}{l}\text { Prophylactic administration of palivizumab to } \\
\text { infants }<5 \text { mo of age (for } 6 \text { mo of protection) during } \\
\text { RSV season (see Table } 3 \text { ) }\end{array}$ \\
\hline $\begin{array}{l}\text { Costs for RSV-related } \\
\text { admissions }\end{array}$ & $\begin{array}{l}\text { Actual cohort of admissions } \\
\text { during } 2009 \text { RSV season }\end{array}$ & - & $\begin{array}{l}\text { Included transportation, admission, physician fees } \\
\text { and accommodation. No additional fees for } \\
\text { resuscitation procedures, emergency visits, } \\
\text { medications, outpatient follow-up, underestimating } \\
\text { costs. }^{10}\end{array}$ \\
\hline $\begin{array}{l}\text { Cost of transportation } \\
\text { to hospital }\end{array}$ & $\begin{array}{l}\text { Actual amounts invoiced by } \\
\text { medical evacuation companies } \\
\text { for each medical evacuation }\end{array}$ & - & Source: medical evacuation companies/airlines \\
\hline $\begin{array}{l}\text { Cost of transportation } \\
\text { back to home } \\
\text { community }\end{array}$ & $\begin{array}{l}\text { Equivalent of regularly } \\
\text { scheduled economy flight }\end{array}$ & Minimum estimate & $\begin{array}{l}\text { Source: directly from commercial airlines. } \\
\text { Assumed return flight was economy commercial } \\
\text { airlines, when sometime patients are transported } \\
\text { by air ambulance with medical personnel. }\end{array}$ \\
\hline Inpatient costs & $\begin{array}{l}\text { Actual costs charged by hospital } \\
\text { per day of hospital stay, } \\
\text { differentiated by ward/ICU }\end{array}$ & - & $\begin{array}{l}\text { Source: territorial governments, hospital finance } \\
\text { departments }\end{array}$ \\
\hline Physician cost & $\begin{array}{l}\text { Estimated from OHIP Schedule } \\
\text { of Benefits and Fees for } \\
\text { pediatrics differentiated by day } \\
\text { of admission, ward/ICU fees and } \\
\text { whether mechanical ventilation } \\
\text { required }\end{array}$ & - & $\begin{array}{l}\text { This involves } 9 \text { hospitals where OHIP billings were } \\
\text { mid-range. Exclusion of after-hours, emergency and } \\
\text { procedural fees gives minimum estimates of costs. }\end{array}$ \\
\hline Risk reduction & $96 \%$ & $88 \%$ scenario C & For preterm Inuit infants in Nunavut ${ }^{13}$ \\
\hline Palivizumab cost & $\begin{array}{l}\$ 225.75 \text { per } \mathrm{kg} \text { of estimated } \\
\text { weight }+5 \% \text { wastage }+\$ 50 \\
\text { administration }\end{array}$ & $\begin{array}{l}\$ 225.75 \text { per } \mathrm{kg} \text { of } \\
\text { estimated weight } \\
+15 \% \text { wastage }+ \\
\$ 50 \text { administration }\end{array}$ & $\begin{array}{l}\text { Source: AbbVie Canada, as actual drug acquisition } \\
\text { cost (see Table 3). Sensitivity analysis increases } \\
\text { wastage threefold. Assumes vial sharing. }\end{array}$ \\
\hline Estimated weight & $\begin{array}{l}\text { Weight at } 50 \% \text { percentile for } \\
\text { each month of age from CDC } \\
\text { growth charts }\end{array}$ & - & $\begin{array}{l}\text { CDC chosen rather than World Health Organization } \\
\text { to have higher estimates of cost }\end{array}$ \\
\hline
\end{tabular}


the Kivalliq Region; the cost in Nunavik was low, at \$15 601 . Exclusion of Iqaluit, in the Qikiqtaaluk Region, and Nunavut resulted in considerable lowering of the ICERs. In scenario C (Table 6), which was "a worst-case" scenario with a risk reduction of $88 \%$ and $15 \%$ wastage, cost savings in the Kitikmeot Region was still \$26 877, while the cost in the Kivalliq Region and Nunavik remained below $\$ 50000$. When scenario A was directly compared to scenario B, scenario B was more costeffective in all regions except the Kitikmeot Region (Table 7).

\section{Interpretation}

We found high variability in the cost-effectiveness of palivizumab prophylaxis for infection due to respiratory syncytial virus in healthy term infants across the Canadian Arctic, from a prohibitive cost of $\$ 546115$ per hospital admission avoided in the Northwest Territories to savings of up to $\$ 48549$ in the Kitikmeot Region. Universal prophylaxis in the Qikiqtaaluk Region did not appear to be cost-effective; however, this

Table 2: Costs for admissions related to respiratory syncytial virus (RSV)

\begin{tabular}{|c|c|c|c|c|c|c|}
\hline \multirow[b]{2}{*}{ Costs } & \multirow[b]{2}{*}{$\begin{array}{l}\text { Northwest } \\
\text { Territories }\end{array}$} & \multicolumn{4}{|c|}{ Nunavut } & \multirow[b]{2}{*}{ Nunavik } \\
\hline & & Overall & Kitikmeot Region & Kivalliq Region & $\begin{array}{l}\text { Qikiqtaaluk } \\
\text { Region }\end{array}$ & \\
\hline $\begin{array}{l}\text { No. of RSV-related } \\
\text { admissions }\end{array}$ & 8 & 52 & 22 & 18 & 12 & 30 \\
\hline $\begin{array}{l}\text { Total cost of all RSV-related } \\
\text { admissions, } \$\end{array}$ & 177256 & 2871137 & 1496365 & 1094603 & 280169 & 632139 \\
\hline $\begin{array}{l}\text { Total transportation (range } \\
\text { per admission) }\end{array}$ & $\begin{array}{c}48243 \\
(0-24564)\end{array}$ & $\begin{array}{c}795915 \\
(0-41175)\end{array}$ & $\begin{array}{c}486753 \\
(15211-41175)\end{array}$ & $\begin{array}{c}216086 \\
(3448-22501)\end{array}$ & $\begin{array}{c}93077 \\
(0-18657)\end{array}$ & $\begin{array}{c}146364 \\
(0-22860)\end{array}$ \\
\hline $\begin{array}{l}\text { Total inpatient (range per } \\
\text { admission) }\end{array}$ & $\begin{array}{c}114660 \\
(9360-18720)\end{array}$ & $\begin{array}{c}1932089 \\
(5218-209266)\end{array}$ & $\begin{array}{c}950705 \\
(10530-166773)\end{array}$ & $\begin{array}{c}815436 \\
(5218-209266)\end{array}$ & $\begin{array}{c}165948 \\
(6396-31308)\end{array}$ & $\begin{array}{c}414340 \\
(2506-88200)\end{array}$ \\
\hline Total physician & 14353 & 123933 & 53958 & 49131 & 20845 & 62135 \\
\hline Total accommodation & 0 & 19200 & 4950 & 13950 & 300 & 9300 \\
\hline $\begin{array}{l}\text { Average cost (range) per } \\
\text { RSV-related admission, } \$\end{array}$ & $\begin{array}{c}22157 \\
(10988-45225)\end{array}$ & $\begin{array}{c}55214 \\
(12856-240410)\end{array}$ & $\begin{array}{c}68017 \\
(31196-217 \text { 430) }\end{array}$ & $\begin{array}{c}60811 \\
(17454-240410)\end{array}$ & $\begin{array}{c}23347 \\
(17276-44277)\end{array}$ & $\begin{array}{c}21071 \\
(3978-115418)\end{array}$ \\
\hline
\end{tabular}

Table 3: Cost, doses and population at risk for universal palivizumab prophylaxis for healthy infants with scenarios $A^{*}$ and $B \dagger$ during the 2009 RSV season

Month; monthly cost per dose per eligible healthy term infant, \$

\begin{tabular}{|lccccccc} 
Age; weight, kg & December 2008 & January 2009 & February 2009 & March 2009 & April 2009 & May 2009 \\
\hline Birth; 3.5 & 880 & 880 & 880 & 880 & 880 & 880 \\
\hline 1 mo; 4.3 & 1069 & 1069 & 1069 & 1069 & 1069 & 1069 \\
\hline 2 mo; 5.05 & 1247 & 1247 & 1247 & 1247 & 1247 & 1247 \\
\hline 3 mo; 5.75 & 1413 & 1413 & 1413 & 1413 & 1413 & 1413 \\
\hline 4 mo; 6.45 & 1579 & 1579 & 1579 & 1579 & 1579 & 1579 \\
\hline 5 mo; 7.0 & 1709 & 1709 & 1709 & 1709 & 1709 & 1709 \\
\hline 6 mo; 7.55 & - & 1840 & 1840 & 1840 & 1840 & 1840 \\
\hline 7 mo; 8.05 & - & - & 1958 & 1958 & 1958 & 1958 \\
\hline 8 mo; 8.45 & - & - & - & 2053 & 2053 & 2053 \\
\hline 9 mo; 8.85 & - & - & - & - & 2148 & 2148 \\
\hline 10 mo; 9.25 & - & - & - & - & - & 2243 \\
\hline Sum scenario A & 7897 & 9737 & 11695 & 13748 & 15896 & 18139 \\
\hline Sum scenario B & 7897 & 7897 & 7897 & 7897 & 7897 & 7897 \\
\hline
\end{tabular}

Note: RSV = respiratory syncytial virus.

*Scenario A: Eligible infants are those who would be less than 6 months of age by Jan. 1, 2009 or born before May 31, 2009. Prophylaxis is stopped by May 31, 2009.

Annual cost per region $=\$ 6423.82 \times$ number of births/year. Monthly doses $=$ number of doses per month $\times 1 / 12 \times$ births/year. Annual doses $=51 \times 1 / 12$ births/year $=4.25 \times$ births/year. Population at risk $=51 / 72 \times$ births/year.

†Scenario B: Eligible infants are those who would be less than 6 months of age by Jan. 1, 2009 or born before May 31, 2009. Prophylaxis is stopped by 6 months of age. Model assumes that an equivalent number of infants are born as surpass the age criteria. Annual cost per region $=\$ 7897 / \mathrm{month} \times 6 / 12$ births/year $=\$ 3947.29 \times$ births. Monthly doses $=$ number of doses per month $\times 1 / 12$ birth/year $=6 / 12 \times$ births. Annual doses $=6 \times 6 / 12$ births/year. Population at risk $=36 / 72 \times$ births/year. 
region had incomplete testing. ${ }^{15}$ There may be a protective factor in Iqaluit as only 1 admitted infant resided there; ${ }^{5}$ exclusion of Iqaluit would allow resources to be transferred to higher-risk areas.

In implementing palivizumab prophylaxis in healthy Inuit infants in the Canadian Arctic, scenario B is preferred except in the Kitikmeot Region, where prophylaxis to the end of the respiratory syncytial virus season was the most cost-effective. In the surveillance study, the median age at admission was 114.5 days, and the risk of longer length of stay decreased by $32.2 \%$ for every 30 -day increase in age. ${ }^{15}$ Outside the Kitikmeot Region, the additional resources needed to provide prophylaxis to older infants, who are at decreasing risk of admission for respiratory syncytial virus infection with increasing age, could be reallocated to those at higher risk.

The tolerance for cost-effectiveness among countries and health care settings is variable, and implementation of a policy change depends on numerous factors. In general, an ICER threshold of $\$ 50000$ per hospital admission avoided is commonly accepted in North America. ${ }^{14,19}$ In the current analysis, the Kitikmeot Region, Kivalliq Region and Nunavik were all below this threshold.

Harris and colleagues ${ }^{16}$ performed a cost analysis comparing palivizumab prophylaxis versus no prophylaxis in Canadian children less than 2 years of age with hemodynamically significant congenital heart disease. The rate of admission for respiratory syncytial virus infection in the study period for the historical cohort was 29.1/1000. The incremental cost of providing prophylaxis to 292 children at risk was \$2 421264 for an estimated $42 \%$ risk reduction to 5 admissions, for an ICER of \$672 573 per hospital admission avoided. In Canada, populations with lower rates of respiratory syncytial virus infection with less severe disease continue to receive prophylaxis with palivizumab, at ICERs much higher than the accepted threshold, whereas term Inuit infants in high-risk regions do not.

In an analysis of the cost-effectiveness of palivizumab prophylaxis in term Inuit infants less than 6 months of age of all gestational ages in rural communities in the Qikiqtaaluk Region in 2002, the ICER was estimated at $\$ 24750$ per quality-adjusted life-year, and palivizumab prophylaxis was

Table 4: Scenario A: Cost-effectiveness of palivizumab prophylaxis versus no prophylaxis in healthy term infants who were less than 6 months of age at the start of the 2009 RSV season or were born during the season per RSV-related hospital admission avoided

\begin{tabular}{|c|c|c|c|c|c|c|c|c|}
\hline Variable & $\begin{array}{l}\text { Northwest } \\
\text { Territories }\end{array}$ & Nunavut & $\begin{array}{l}\text { Nunavut } \\
\text { without } \\
\text { Iqaluit }\end{array}$ & $\begin{array}{l}\text { Kitikmeot } \\
\text { Region }\end{array}$ & $\begin{array}{l}\text { Kivalliq } \\
\text { Region }\end{array}$ & $\begin{array}{l}\text { Qikiqtaaluk } \\
\text { Region }\end{array}$ & $\begin{array}{l}\text { Qikiqtaaluk } \\
\text { Region } \\
\text { without } \\
\text { Iqaluit }\end{array}$ & Nunavik \\
\hline Total births in 2009 & 739 & 816 & 701 & 114 & 245 & 457 & 342 & 250 \\
\hline Healthy newborns* & 679.9 & 750.7 & 644.9 & 104.9 & 225.4 & 420.4 & 314.6 & 230 \\
\hline $\begin{array}{l}\text { Estimated rate of RSV-related } \\
\text { admission per } 1000 \text { population at } \\
\text { risk } \dagger\end{array}$ & 16.6 & 97.8 & 111.6 & 296.1 & 112.7 & 40.3 & 49.4 & 184.1 \\
\hline \multicolumn{9}{|c|}{ Base case: no prophylaxis, RSV-related admissions in healthy term infants admitted Jan. 1 to June 30,2009} \\
\hline No. of RSV-related admissions & 8 & 52 & 51 & 22 & 18 & 12 & 11 & 30 \\
\hline Total cost of admissions, $\$$ & 177256 & 2871137 & 2856561 & 1496365 & 1094603 & 280169 & 265593 & 632139 \\
\hline \multicolumn{9}{|c|}{ Scenario A: universal palivizumab prophylaxis for healthy term infants, with $96 \%$ risk reduction } \\
\hline No. of RSV-related admissions & 0.3 & 2.1 & 2.0 & 0.9 & 0.7 & 0.5 & 0.4 & 1.2 \\
\hline Total cost of admissions, $\$$ & 7090 & 114845 & 114262 & 59855 & 43784 & 11207 & 10624 & 25286 \\
\hline Estimated cost of palivizumab, $\$$ & 4367555 & 4822362 & 4142722 & 673859 & 1447929 & 2700574 & 2020934 & 1477479 \\
\hline $\begin{array}{l}\text { Total cost (palivizumab + } \\
\text { admissions), \$ }\end{array}$ & 4374645 & 4937207 & 4256984 & 733714 & 1491713 & 2711781 & 2031558 & 1502765 \\
\hline \multicolumn{9}{|l|}{ Scenario A v. base case } \\
\hline $\begin{array}{l}\text { Incremental cost for RSV } \\
\text { prophylaxis, } \$\end{array}$ & 4197389 & 2066070 & 1400423 & -762652 & 397111 & 2431611 & 1765965 & 870625 \\
\hline $\begin{array}{l}\text { Incremental cases of RSV infection } \\
\text { avoided }\end{array}$ & 7.7 & 49.9 & 49.0 & 21.1 & 17.3 & 11.5 & 10.6 & 28.8 \\
\hline $\begin{array}{l}\text { ICER per RSV-related admission } \\
\text { avoided, } \$\end{array}$ & 545115 & 41404 & 28580 & -36145 & 22954 & 211444 & 166600 & 30230 \\
\hline $\begin{array}{l}\text { NNT } \ddagger \text { to prevent } 1 \text { RSV-related } \\
\text { admission }\end{array}$ & 62.7 & 10.7 & 9.3 & 3.5 & 9.2 & 25.8 & 21.1 & 5.7 \\
\hline \multicolumn{9}{|c|}{$\begin{array}{l}\text { Note: ICER = incremental cost-effectiveness ratio, NNT = number needed to treat, RSV = respiratory syncytial virus. } \\
{ }^{*} \text { Estimated to be } 92 \% \text { of all newborns. } \\
\text { †Admissions for RSV infection between Jan. } 1 \text { and June } 30,2009 \text {, with population at risk of healthy term infants born after July } 1,2008, \text { to May } 31,2009 . \\
\ddagger 1 / \text { absolute risk reduction. Absolute risk reduction was defined as the untreated admission RSV rate }-([1-\text { efficacy }] \times \text { untreated RSV admission rate). Untreated admission } \\
\text { rate = number of admissions with RSV in those not treated/population at risk. }\end{array}$} \\
\hline
\end{tabular}


seen as a cost-saving strategy. ${ }^{19}$ In Australia, although indigenous infants have elevated rates of admission for respiratory syncytial virus infection, transportation costs are not substantial, and Reeve and colleagues ${ }^{20}$ estimated the ICER at A $\$ 70$ 000-A \$90 000 per hospital admission avoided.

In implementing a prophylaxis program, other factors such as rate and severity of illness and number needed to treat are taken into consideration in addition to ICERs. During the 2009 respiratory syncytial virus season, the rate of admission for infection due to the virus in Nunavut was about 6 times higher than that in the Northwest Territories, and the rate in the Kitikmeot Region was about 18 times higher, despite a similar birth rate. In addition, the number needed to treat was 18 times higher in the Northwest Territories than in the

Table 5: Scenario B: cost-effectiveness of palivizumab prophylaxis in infants less than 5 months (6 months of protection) versus no prophylaxis of all healthy term infants 6 months of age at the start of the 2009 per RSV-related hospital admission avoided

\begin{tabular}{|c|c|c|c|c|c|c|c|c|}
\hline Variable & $\begin{array}{l}\text { Northwest } \\
\text { Territories }\end{array}$ & Nunavut & $\begin{array}{l}\text { Nunavut } \\
\text { without } \\
\text { Iqaluit }\end{array}$ & Kitikmeot & Kivalliq & Qikiqtaaluk & $\begin{array}{l}\text { Qikiqtaaluk } \\
\text { without } \\
\text { Iqaluit }\end{array}$ & Nunavik \\
\hline Total births in 2009 & 739 & 816 & 701 & 114 & 245 & 457 & 342 & 250 \\
\hline Healthy newborns & 679.9 & 750.7 & 644.9 & 104.9 & 225.4 & 420.4 & 314.6 & 230 \\
\hline $\begin{array}{l}\text { Rate of RSV infection in healthy } \\
\text { infants }<6 \text { mo of age January to } \\
\text { June } 2009 \text {, per } 1000 \text { live births }\end{array}$ & 23.5 & 111.9 & 127.1 & 324.1 & 124.2 & 52.3 & 63.6 & 208.7 \\
\hline \multicolumn{9}{|c|}{ Base case: no prophylaxis, RSV-related admissions in healthy term infants admitted Jan. 1 to June 30,2009} \\
\hline $\begin{array}{l}\text { No. of RSV-related admissions } \\
\text { among infants }<6 \text { mo of age }\end{array}$ & 8 & 42 & 41 & 17 & 14 & 11 & 10 & 24 \\
\hline $\begin{array}{l}\text { No. of RSV-related admissions } \\
\text { among infants } \geq 6 \text { mo of age }\end{array}$ & 0 & 10 & 10 & 5 & 4 & 1 & 1 & 6 \\
\hline $\begin{array}{l}\text { Total cost of RSV-related } \\
\text { admissions among infants }<6 \text { mo } \\
\text { of age, } \$\end{array}$ & & 2476100 & 2461523 & 1255638 & 964915 & 255547 & 240971 & 571929 \\
\hline $\begin{array}{l}\text { Total cost of RSV-related } \\
\text { admissions among infants } \geq 6 \text { mo } \\
\text { of age, } \$\end{array}$ & 0 & 395037 & 395038 & 240727 & 129688 & 24622 & 24622 & 60210 \\
\hline $\begin{array}{l}\text { Total cost of all RSV-related } \\
\text { admissions, \$ }\end{array}$ & 177256 & 2871137 & 2856561 & 1496365 & 1094603 & 280169 & 265593 & 632139 \\
\hline \multicolumn{9}{|c|}{ Scenario B: palivizumab prophylaxis of healthy term infants up to 5 months of age, with $96 \%$ risk reduction } \\
\hline $\begin{array}{l}\text { No. of RSV-related admissions } \\
\text { among infants }<6 \text { mo (received } \\
\text { prophylaxis) }\end{array}$ & 0.3 & 1.7 & 1.6 & 0.7 & 0.6 & 0.4 & 0.4 & 1.0 \\
\hline $\begin{array}{l}\text { No. of RSV-related admissions } \\
\text { among infants } \geq 6 \text { mo of age (did } \\
\text { not receive prophylaxis) }\end{array}$ & 0 & 10 & 10 & 5 & 4 & 1 & 1 & 6 \\
\hline $\begin{array}{l}\text { Costs of admissions of infants } \\
<6 \text { mo of age, } \$\end{array}$ & 7090 & 99044 & 98461 & 50226 & 38597 & 10222 & 9639 & 22877 \\
\hline $\begin{array}{l}\text { Cost of admissions of infants } \\
\geq 6 \text { mo of age, } \$\end{array}$ & 0 & 395037 & 395038 & 240727 & 129688 & 24622 & 24622 & 60210 \\
\hline $\begin{array}{l}\text { Total cost of all RSV-related } \\
\text { admissions, } \$\end{array}$ & 7090 & 494081 & 493499 & 290953 & 168285 & 34844 & 34261 & 83087 \\
\hline Estimated cost of palivizumab, \$ & 2683762 & 2963231 & 2545607 & 414071 & 889719 & 1659441 & 1241817 & 907877 \\
\hline $\begin{array}{l}\text { Total costs (palivizumab + all } \\
\text { RSV-related admissions), } \$^{*}\end{array}$ & 2690852 & 3457312 & 3039106 & 705024 & 1058004 & 1694285 & 1276078 & 990964 \\
\hline \multicolumn{9}{|l|}{ Scenario B v. base case } \\
\hline $\begin{array}{l}\text { Incremental cost for RSV } \\
\text { prophylaxis, } \$\end{array}$ & 2513597 & 586175 & 182545 & -791342 & -36599 & 1414116 & 1010486 & 358825 \\
\hline $\begin{array}{l}\text { Incremental RSV-related } \\
\text { admissions avoided }\end{array}$ & 7.7 & 30.3 & 29.4 & 11.3 & 9.4 & 9.6 & 8.6 & 17 \\
\hline $\begin{array}{l}\text { ICER per RSV-related admission } \\
\text { avoided, } \$\end{array}$ & 326441 & 14545 & 4633 & -48549 & -2731 & 133407 & 105259 & 15601 \\
\hline $\begin{array}{l}\text { NNT to prevent } 1 \text { RSV-related } \\
\text { admission among infants }<6 \text { mo of } \\
\text { age }\end{array}$ & 44.3 & 9.3 & 8.2 & 3.2 & 8.4 & 19.9 & 16.4 & 5.0 \\
\hline
\end{tabular}


Table 6: Scenario C: cost-effectiveness of palivizumab prophylaxis versus no prophylaxis in healthy term infants who were less than 6 months of age at the start of the 2009 RSV season or were born during the season per RSV-related hospital admission avoided, with $88 \%$ risk reduction and $15 \%$ palivizumab wastage

\begin{tabular}{|c|c|c|c|c|c|c|c|c|}
\hline Variable & $\begin{array}{l}\text { Northwest } \\
\text { Territories }\end{array}$ & Nunavut & $\begin{array}{l}\text { Nunavut } \\
\text { without } \\
\text { Iqaluit }\end{array}$ & Kitikmeot & Kivalliq & Qikiqtaaluk & $\begin{array}{l}\text { Qikiqtaaluk } \\
\text { without } \\
\text { lqaluit }\end{array}$ & Nunavik \\
\hline Total births in 2009 & 739 & 816 & 701 & 114 & 245 & 457 & 342 & 250 \\
\hline Healthy newborns & 679.9 & 750.7 & 644.9 & 104.9 & 225.4 & 420.4 & 314.6 & 230 \\
\hline $\begin{array}{l}\text { Estimated rate of RSV-related } \\
\text { admissions per } 1000 \\
\text { population at risk } \dagger\end{array}$ & 16.6 & 97.8 & 111.6 & 296.1 & 112.7 & 40.3 & 49.4 & 184.1 \\
\hline \multicolumn{9}{|c|}{ Base case: no prophylaxis, RSV-related admissions in healthy term infants } \\
\hline $\begin{array}{l}\text { Total no. of RSV-related } \\
\text { admissions documented in } \\
2009 \text { in healthy term infants }\end{array}$ & 8 & 52 & 51 & 22 & 18 & 12 & 11 & 30 \\
\hline Total cost of admissions, $\$$ & 177256 & 2871137 & 2856561 & 1496365 & 1094603 & 280169 & 265593 & 632139 \\
\hline \multicolumn{9}{|c|}{ Scenario C: universal palivizumab prophylaxis of healthy term infants, with $88 \%$ risk reduction } \\
\hline $\begin{array}{l}\text { Total no. of RSV-related } \\
\text { admissions }\end{array}$ & 0.96 & 6.24 & 6.12 & 2.64 & 2.16 & 1.44 & 1.32 & 3.6 \\
\hline $\begin{array}{l}\text { Total costs of RSV-related } \\
\text { admissions, } \$\end{array}$ & 21271 & 344536 & 342787 & 179564 & 131352 & 33620 & 31871 & 75857 \\
\hline $\begin{array}{l}\text { Estimated cost of } \\
\text { palivizumab, } \$\end{array}$ & 5009170 & 5653859 & 4874975 & 840427 & 1708285 & 3105148 & 2326264 & 1720849 \\
\hline $\begin{array}{l}\text { Total costs (palivizumab + } \\
\text { RSV-related admissions), } \$\end{array}$ & 5030441 & 5998395 & 5217762 & 1019991 & 1839637 & 3138768 & 2358135 & 1796706 \\
\hline \multicolumn{9}{|l|}{ Scenario $\mathrm{C}$ v. base case } \\
\hline $\begin{array}{l}\text { Incremental cost for RSV } \\
\text { prophylaxis, \$ }\end{array}$ & 4853185 & 3127259 & 2361202 & -476374 & 745035 & 2858599 & 2092542 & 1164566 \\
\hline $\begin{array}{l}\text { Incremental RSV-related } \\
\text { admissions avoided }\end{array}$ & 7.0 & 45.8 & 44.9 & 19.4 & 15.8 & 10.6 & 9.7 & 26.4 \\
\hline $\begin{array}{l}\text { ICER per RSV-related } \\
\text { admission avoided, } \$\end{array}$ & 714580 & 69087 & 52898 & -26877 & 47201 & 277275 & 221724 & 44976 \\
\hline $\begin{array}{l}\text { NNT to prevent } 1 \text { RSV- } \\
\text { related admission }\end{array}$ & 77.2 & 13.1 & 11.5 & 4.3 & 11.4 & 31.8 & 26.0 & 7.0 \\
\hline
\end{tabular}

Kitikmeot Region with scenario A and 14 times higher with scenario B. The rates of admission for respiratory syncytial virus infection are also extremely high in Nunavik, with a low number needed to treat (5 to 6 ). The costs associated with medical evacuations with comparatively shorter distance are less in Nunavik than in other regions; however, the ICER is below the accepted threshold. In addition to low ICERs, the rates of admission for respiratory syncytial virus infection in the Kitikmeot Region and Nunavik are high, given that the population has no typical risk factors for infection due to this virus. This population experiences substantial morbidity, with long hospital and intensive care unit stays and high proportions of infants needing mechanical ventilation. ${ }^{2,3,5-7,15}$

The Canadian Paediatric Society guidelines recommend that term Inuit infants less than 6 months of age residing in remote communities with a persistently high rate of hospital admission for respiratory syncytial virus infection should be considered for palivizumab prophylaxis. ${ }^{10,13}$ The combination of extremely high admission rates for infection due to this virus together with high inpatient and medical transportation costs requires recognition that infants residing in the Kitik- meot and Kivalliq Regions and Nunavik represent unique populations at risk. Our results provide further justification for respiratory syncytial virus prophylaxis in high-risk regions with low ICERs.

\section{Limitations}

This study likely underestimates the costs and the number of admissions related to respiratory syncytial virus. Not all the infants admitted for lower respiratory tract infections had viral testing, with lower proportions in the Qikiqtaaluk Region; this may have resulted in underestimation of cases of respiratory syncytial virus infection. The findings should therefore be interpreted with caution. There may be long-term morbidities from hospital admissions for the virus outside of the period studied. Ideally, more than 1 year of data would be analyzed to ensure the robustness of the findings; however, previous studies in the areas with the highest rates of admission related to respiratory syncytial virus have yielded similar results. ${ }^{2,3,7,10} \mathrm{~A}$ further limitation is that the effectiveness of our model would be reduced with decreased compliance. Finally, we used estimated actual costs rather than probabilistic modelling. How- 


\section{OPEN}

Research

Table 7: ICERs for palivizumab prophylaxis for healthy term infants in the Canadian Arctic, comparing scenario A, in which prophylaxis is continued to end of RSV season, to scenario B, in which prophylaxis is stopped at 5 months of age

\begin{tabular}{|c|c|c|c|c|c|c|c|c|}
\hline Variable & $\begin{array}{l}\text { Northwest } \\
\text { Territories }\end{array}$ & Nunavut & $\begin{array}{l}\text { Nunavut } \\
\text { without } \\
\text { Iqaluit }\end{array}$ & $\begin{array}{l}\text { Kitikmeot } \\
\text { Region }\end{array}$ & $\begin{array}{l}\text { Kivalliq } \\
\text { Region }\end{array}$ & $\begin{array}{l}\text { Qikiqtaaluk } \\
\text { Region }\end{array}$ & $\begin{array}{c}\text { Qikiqtaaluk } \\
\text { Region } \\
\text { without } \\
\text { Iqaluit }\end{array}$ & Nunavik \\
\hline \multicolumn{9}{|l|}{ Base case (no prophylaxis) } \\
\hline Total costs, $\$$ & 177256 & 2871137 & 2856561 & 1496365 & 1094603 & 280169 & 265593 & 632139 \\
\hline No. of admissions for RSV infection & 8 & 52 & 51 & 22 & 18 & 12 & 11 & 30 \\
\hline \multicolumn{9}{|l|}{ Scenario $\mathrm{A}$} \\
\hline Total costs, $\$$ & 4374645 & 4937207 & 4256984 & 733714 & 1491713 & 2711781 & 2031558 & 1502765 \\
\hline No. of admissions for RSV infection & 0.3 & 2.1 & 2 & 0.9 & 0.7 & 0.5 & 0.4 & 1.2 \\
\hline \multicolumn{9}{|l|}{ Scenario B } \\
\hline Total costs, $\$$ & 2690852 & 3457312 & 3039106 & 705024 & 1058004 & 1694285 & 1276078 & 990964 \\
\hline No. of admissions for RSV infection & 0.3 & 11.7 & 11.6 & 5.7 & 4.6 & 1.4 & 1.4 & 7 \\
\hline \multicolumn{9}{|l|}{ Scenario A v. base case } \\
\hline Incremental costs, \$ & 4197389 & 2066070 & 1400423 & -762652 & 397111 & 2431611 & 1765965 & 870625 \\
\hline $\begin{array}{l}\text { Incremental no. of RSV-related } \\
\text { admissions }\end{array}$ & 7.7 & 49.9 & 49 & 21.1 & 17.3 & 11.5 & 10.6 & 28.8 \\
\hline $\begin{array}{l}\text { ICER (cost per RSV-related } \\
\text { admission avoided), \$ }\end{array}$ & 545115 & 41404 & 28580 & -36145 & 22954 & 211444 & 166600 & 30230 \\
\hline \multicolumn{9}{|l|}{ Scenario B v. base case } \\
\hline Incremental costs, $\$$ & 2513597 & 586175 & 182545 & -791342 & -36599 & 1414116 & 1010486 & 358825 \\
\hline $\begin{array}{l}\text { Incremental no. of RSV-related } \\
\text { admissions }\end{array}$ & 7.7 & 40.3 & 39.4 & 16.3 & 13.4 & 10.6 & 9.6 & 23 \\
\hline $\begin{array}{l}\text { ICER (cost per RSV-related } \\
\text { admission avoided), } \$\end{array}$ & 326441 & 14545 & 4633 & -48549 & -2731 & 133407 & 105259 & 15601 \\
\hline \multicolumn{9}{|l|}{ Scenario A v. scenario B } \\
\hline Incremental costs, \$ & 1683793 & 1479895 & 1217878 & 28690 & 433709 & 1017496 & 755480 & 511801 \\
\hline $\begin{array}{l}\text { Incremental no. of RSV-related } \\
\text { admissions }\end{array}$ & 0 & 9.6 & 9.6 & 4.8 & 3.9 & 0.9 & 1 & 5.8 \\
\hline $\begin{array}{l}\text { ICER (cost per RSV-related } \\
\text { admission avoided), \$ }\end{array}$ & - & 154156 & 126862 & 5977 & 111207 & 1130551 & 755480 & 88242 \\
\hline
\end{tabular}

ever, providing conservative cost estimates in a mild respiratory syncytial virus season increases the generalizability to other years.

\section{Conclusion}

We found great variability in the ICERs for palivizumab prophylaxis of respiratory syncytial virus infections in healthy term infants in the Canadian Arctic. Palivizumab prophylaxis was cost-effective in the Kitikmeot and Kivalliq regions and Nunavik. In general, stopping prophylaxis at 5 months of age resulted in lower ICERs and is preferred except in the Kitikmeot Region, where prophylaxis should be continued to the end of the respiratory syncytial virus season, as all scenarios resulted in cost savings in this region.

\section{References}

1. Nair H, Nokes DJ, Gessner BD, et al. Global burden of acute lower respiratory infections due to respiratory syncytial virus in young children: a systematic review and meta-analysis. Lancet 2010;375:1545-55.

2. Banerji A. High rates of hospitalisation for bronchiolitis in Inuit children on Baffin Island. Int 7 Circumpolar Health 2001;60:375-9.
3. Young M, Kandola K, Mitchell R, et al. Hospital admission rates for lower respiratory tract infections in infants in the Northwest Territories and the Kitikmeot region of Nunavut between 2000 and 2004. Paediatr Child Health 2007;12:563-6.

4. Carson JB, Postl BD, Spady D, et al. Lower respiratory tract infections among Canadian Inuit Children. Int 7 Circumpolar Health 1984;84:226-8.

5. Banerji A, Greenberg D, White LF, et al. Risk factors and viruses associated with hospitalization due to lower respiratory tract infections in Canadian Inuit children: a case-control study. Pediatr Infect Dis 7 2009;28:697-701.

6. Banerji A, Bell A, Mills EL, et al. Lower respiratory tract infections in Inuit infants on Baffin Island. CMA7 2001;164:1847-50.

7. Banerji A, Lanctôt KL, Paes BA, et al. Comparison of the cost of hospitalization for respiratory syncytial virus disease versus palivizumab prophylaxis in Canadian Inuit infants. Pediatr Infect Dis 7 2009;28:702-6.

8. Shay DK, Holman RC, Newman RD, et al. Bronchiolitis-associated hospitalizations among US children, 1980-1996. 7AMA 1999;282:1440-6.

9. Creery D, Lyer P, Samson L, et al. Costs associated with infant bronchiolitis in the Baffin region of Nunavut. Int 7 Circumpolar Health 2005;64:38-45.

10. Banerji A, Panzov V, Robinson J, et al. The cost of lower respiratory tract infections hospital admissions in the Canadian Arctic. Int $\mathcal{F}$ Circumpolar Health 2013;72. Aug. 5. DOI: 10.3402/ijch.v72i0.21595.

11. Samson L. Prevention of respiratory syncytial virus infection. Paediatr Child Health 2009;14:521-32.

12. Robinson J. Preventing respiratory syncytial virus infections. Paediatr Child Health 2011;16:487-90.

13. Banerji A, Panzov V, Young M, et al. The real-life effectiveness of palivizumab for reducing hospital admissions for respiratory syncytial virus in infants residing in Nunavut. Can Respir 7 2014;21:185-9. 
14. Hussman JM, Li A, Paes B, et al. A review of cost-effectiveness of palivizumab for respiratory syncytial virus. Expert Rev Pharmacoecon Outcomes Res 2012;12:553-67.

15. Banerji A, Panzov V, Young M, et al. Hospital admissions for lower respiratory tract infections among infants in the Canadian Arctic: a cohort study. CMAF Open 2016;4:E615-22.

16. Harris KC, Anis AH, Crosby MC, et al. Economic evaluation of palivizumab in children with congenital heart disease: a Canadian perspective. Can $7 \mathrm{Car}$ diol 2011;27:523.e11-5.

17. Schedule of benefits for physician services under the Health Insurance Act. Toronto: Ontario Ministry of Health and Long-Term Care; 2011. Available: www.health.gov.on.ca/english/providers/program/ohip/sob/physserv/physserv_ mn.html (accessed 2012 Dec. 12)

18. Carbonell-Estrany X, Fullarton J, Rodgers-Gray B, et al. Can we improve the targeting of respiratory syncytial virus (RSV) prophylaxis in infants born 32-35 weeks' gestational age with more informed use of risk factors? 7 Matern Fetal Neonatal Med 2015;28:1133-41.

19. Tam DY, Banerji A, Paes BA, et al. The cost effectiveness of palivizumab in term Inuit infants in the Eastern Canadian Arctic. 7 Med Econ 2009;12:361-70.

20. Reeve CA, Whitehall JS, Buettner PG, et al. Cost-effectiveness of respiratory syncytial virus prophylaxis with palivizumab. 7 Paediatr Child Health 2006; 42 : 253-8.
Affiliations: Li Ka Shing Knowledge Institute (Banerji), St. Michael's Hospital, Toronto, Ont.; Dalla Lana School of Public Health (Banerii), University of Toronto, Toronto, Ont.; Department of Pediatrics (Ng), University of Calgary, Calgary, Alta.; Hospital for Sick Children (Moraes); Applied Health Research Centre (Panzov), Li Ka Shing Knowledge Institute, St. Michael's Hospital, Toronto, Ont.; Stollery Children's Hospital (Robinson) and Department of Pediatrics (Lee), Faculty of Medicine, Edmonton Clinic Health Academy, University of Alberta, Edmonton, Alta.

Contributors: Anna Banerji, Vladimir Panzov, Joan Robinson and Bonita Lee contributed substantially to study conception and design. Kaspar $\mathrm{Ng}$ and Theo Moraes contributed to data analysis and interpretation. All of the authors contributed to drafting and revising the manuscript, approved the final version to be published and agreed to act as guarantors of the work.

Supplemental information: For reviewer comments and the original submission of this manuscript, please see www.cmajopen.ca/content/4/4/ E623/suppl/DC1 